\title{
TRANSFORMATIVE LEARNING DALAM MEMBANGUN PESANTREN BERBASIS MULTIKULTURAL
}

\author{
Syamsul Ma'arif \\ Fakultas Tarbiyah IAIN Walisongo Semarang
}

\begin{abstract}
Abstrak
Semangat membangun pesantren berbasis multikultural, harus diawali dengan perubahan fundamental dalam proses belajar mengajar di pesantren, menuju ke arah transformative learning. Pendidikan pesantren yang cenderung monolog (kaku dan satu arah antara kiyai-santri), perlu digeser ke arah sistem dan metode dialogis-kritis. Dari sistem "pengajian" dan mono-disipliner ke arah "pengkajian" serta bersifat interdisipliner studies. Dengan harapan pesantren yang terkenal sebagai lembaga pendidikan yang selalu berdimensi metafisik ini, terbiasa dengan "perbedaan" dan responsive terhadap perkembangan zaman. Selain itu, pesantren perlu mempersiapkan kurikulum yang dapat menumbuhkan multikulturalisme serta mampu menggali sisi -sisi perdamaian dan toleransi. Tujuan transformative learning di pesantren berbasis multikultural tiada lain adalah mempersiapkan generasi yang inklusif dan akomodatif terhadap keanekaragaman masyarakat, yang memiliki perbedaan agama, etnis dan kultur. Santri yang memiliki wawasan luas dan mampu melintas batas tradisi dan keagamaan serta memiliki kepedulaian terhadap peran agama dalam memecahkan problem sosial yang ada.
\end{abstract}

Kata kunci: pesantren, multikultural dan transformative teaching

\section{TRANSFORMATIVE TEACHING AND DEVELOPING MULITICULTURAL-BASED PESANTREN}

\begin{abstract}
The spirit of developing a multi-cultural-based pesantren must begin with a fundamental change in the teaching and learning process towards transformative teaching in pesantren. Pesantren education which tends to monologues (rigid and one-way between the kyai and santri) has shifted towards a system and method of critical dialog. From pengajian system and monodisciplinary to the assessment and interdisciplinary studies in nature. With the hope that pesantren which is known as metaphysic dimension educational institution will be used to differences and be responsive to changes. Besides, pesantren needs to prepare the curriculum which can encourage multi-culturalism and discover aspects of peace and tolerance. The objective of transformative teaching in multi-culture-based pesantren is not more than preparing generation which is inclusive and accomodative to highly varied societies, which have religious, ethnic, and culture differences. The santri produced are those who have wide horizon and are able to cross over tradition and religious borders are concerned with the role of religion in solving social problems.
\end{abstract}

Keywords: pesantren, multikultural and transformative teaching 


\section{PENDAHULUAN}

Membangun sebuah institusi pendidikan yang bertujuan untuk melahirkan peserta didik yang memiliki wawasan luas dan bisa berinteraksi dengan semua komunitas dengan keanekaragaman budaya, agama dan etnis adalah sebuah keniscayaan. Lebih-lebih di era globalisasi sekarang yang menuntut semua masyarakat dunia bisa bersatu dan bekerjasama dalam sebuah dunia yang disebut oleh Jan Nederveen Pieterse (2004), dengan istilah " $a$ single world society, global society".

Itu artinya, sebagai bagian dari masyarakat global, pesantren juga dituntut untuk melaksanakan dan mengembangkan nilai-nilai yang menjadi tuntutan masyarakat global tersebut. Yaitu, sebuah sikap yang dapat menghargai dan menerapkan nilai-nilai demokrasi, pluralisme dan HAM. Untuk keperluan ini, penting bagi setiap kiai dan pengurus pesantren menunjukkan kepada khalayak akan arti penting pesantren sebagai wahana pencerdasan dan pemberdayaan masyarakat (empowering people) dan membentuk pesantren berbasis multikulturalis. Sebuah pesantren masa depan yang menawarkan konsep baru bagi para santri untuk menghadapi tuntutan globalisasi.

Sebenarnya nilai-nilai seperti demokrasi, pluralism dan HAM sangat compatible dengan pesantren. Apalagi kalau melihat pesantren sebagai sebuah lembaga pendidikan tertua di Indonesia dan pada mulanya terkenal sebagai lembaga pendidikan Islam dengan tujuan utamanya adalah mengajarkan ilmu-ilmu agama dan akhlak mulia bagi para santri. Karakteristik yang sangat menonjol di pesantren sebagai lembaga pendidikan bisa dikatakan multikulturalis. Sebab, pembelajaran di pesantren lebih menekankan pada karakter moral dan indigenous budaya lokal Jawa. Sementara wajah Islam yang ditrasmisikan para kiai di pesantren pada dasarnya adalah Islam inklusif dan menebarkan kedamaian di muka bumi (rahmatan lil'alamin). Para kiai pesantren biasanya juga meneruskan ajaran para walisongo yang selalu mengajarkan sopan santun, toleran dan menghormati budaya lokal.

Bahkan berkaca pada realitas sejarah, pada dasarnya pesantren dilahirkan untuk memberikan respon terhadap situasi dan kondisi sosial suatu masyarakat yang tengah dihadapkan pada runtuhnya sendi-sendi moral melalui transformasi nilai yang ditawarkanya (amar ma'ruf nahi munkar). Kehadiran pesantren bisa disebut sebagai agen perubahan sosial yang selalu melakukan kerja-kerja pembebasan pada masyarakat dari keburukan moral, penindasan dan kemiskinan. Selain itu, berdirinya pesantren juga memiliki misi untuk menyebarluaskan informasi ajaran universalitas Islam keseluruh pelosok Nusantara yang berwatak pluralis (Saifudin Zuhri, 1999: 201).

Tak salah jika melihat sosok pesantren, terlepas dari segala kekuranganya yang oleh Gerrtz dilukiskan sebagai "Sekolah Quran Pedesaan" yang menjadi arteri yang memompakan darah segar ke seluruh tubuh umat Islam Indonesia. Para santri merupakan sekelompok kecil orang yang mewakili ortodoksi dan keimanan sejati di tengah hutan belantara. Berbagai jenis pesantren yang berlokasi di kawasan pedesaan itu bercorak mandiri dan mistik yang merupakan kompromi (antara ortodoksi) dengan kepercayaan yang dianut kaum "abangan" (Abdul Aziz dalam 
INSEP, 2011). Tapi peran serta kontribusi pesantren dalam dinamika sejarah di Indonesia tidak bisa dianggap "enteng". Bukankah pesantren terkenal sebagai penjaga moral dan pembela idiologi pancasila yang tangguh?

\section{MENUJU TRANSFORNATIVE LEARNING DI PESANTREN}

Melihat gambaran sepintas pesantren di atas, dapat dikatakan sesungguhnya pesantren pada wataknya sangat pluralis dan akomodatif dengan keanekaragamana yang menjadi karakter bangsa Indonesia. Pertanyaanya yang muncul kemudian adalah; apakah pesantren masih menjaga dan melestarikan nilai-nilai kebajikan terutama menyangkut nilai multikultural? Pembelajaran seperti apakah yang dapat diterapkan dalam pesantren berbasis multikultural? Sebab melihat pembelajaran di pesantren selama ini oleh banyak kalangan dilihat justru sangat berlawanan dengan nilainilai globalisasi tersebut. Sebab tramsmisi keilmuan yang dipraktekkan biasanya menggambarkan komunikasi tatap muka, oral, dan personal. Bahkan Zamaksyari Dhofier menyebut interaksi komunikasi antara kiai-santri di pesantren tidak equel (setara), pembelajaran pun cenderung bersifat satu arah: kiai memberi dan santri menerima (Dhofier, 1994). Inilah model pembelajaran yang oleh Paulo Freire disebut dengan istilah gaya bank.

Tentu saja, model pembelajaran seperti itu kurang cocok bila diterapkan pada pesantren yang berbasis multikultural. Sebab model yang cocok untuk pesantren berbasis multikultural adalah transformative learning. Dimana Konsep dan paradigm yang melatarbelakangi transformative learning adalah dipengaruhi oleh paradigm membangun kesadaran ala Paulo Freire, hegemoni dari Gramsci dan Hebermas. Meziro mendefinisikan Transformative Learning adalah sebuah proses dimana kita mentrasformasikan cara pandang kita yang taken-for-granted. Dimana dalam proses pembelajaran lebih menekankan pada berpikir reflektif dan dialog terbuka (Zamroni, 2011).

Model transformative learning perlu diterapkan di pesantren untuk keperluan melakukan perubahan ke arah sikap untuk bisa menerima kenyataan sesungguhnya perbedaan adalah sunnatullah—sebuah ciri dari multikultural—dan bisa saling menghormati dan bekerjasama demi kedamaian abadi di dunia ini. Pesantren perlu melakukan gerakan penyadaran dengan meletakkan pesantren dalam proses transformasi dalam keseluruhan sistem perubahan sosial. Setiap usaha pesantren perlu melakukan transformasi hubungan antara kiyai sebagai fasilitator dan santri sebagai murid pesantren. Dengan kata lain perlu ada perubahan pandangan di pesantren dari teacher centered ke arah student centered dengan penekanan pada paradigma kritis.

Selain itu, model transformative learning tersebut bisa merangsang pemahaman, peran dan ketrampilan masyarakat pesantren. Secara efektif model ini akan memberikan panduan dalam melakukan perbaikan atau perubahan pada pesantren-terutama terkait upaya penanaman dan transfer of knowledge tentang nilai-nilai multikultural di masyarakat dan memberikan sejumlah pengalaman baru yang bermanfaat bagi pengembangan peran dan memecahkan permasalahan yang dihadapi. Seperti bagaimana masyarakat pesantren harus menanggulangi dan ikut memecahkan 
permasalah konflik dan sentiment keagamaan yang sedang menghantui masyarakat Indonesia dewasa ini.

Dalam konteks transformative learning di pesantren, selain memperhatikan persoalan paradigma seperti di atas. Pesantren juga perlu merancang seperangkat kurikulum, tujuan dan teknik atau metode yang harus digunakan agar upaya membangun pesantren berbasis multikultural bisa terwujud. Dalam kontek pesantren berbasis multikultural tujuan yang harus direalisasikan pesantren adalah membentuk santri yang berwatak pluralis. Maksudnya, pesantren harus mempersiapkan sungguh-sungguh para santri yang bisa menerima dan menyakini adanya perbedaan di tengah masyarakat. Untuk keperluan ini, pesantren harus menjadi sebuah pendidikan sebagaimana ungkapan Sleeter (dalam Burnet, 1991: 1) sebagai any set of proces by which schools work with rather than against oppressed group. Begitu pula pesantren harus merancang menjadi sebuah lembaga pendidikan untuk student of color-sebagaimana ungkapan Banks, dalam bukunya An introduction to Multicultural education (2002: 22-23). Sehingga terjadi peningkatan persamaan pendidikan bagi kelompok gender, dan santri dari berbagai etnik, kelompok kultural, dan murid dengan pengecualian. Tujuan pesantren multikultural ini berkaitan dengan pentingnya tujuan pendidikan global-untuk membantu murid ( santri) membangun kompetensi lintas budaya dalam sebuah budaya yang melintas dari ikatan nasional mereka dan pemahaman yang dibutuhkan untuk mengerti bagaimana seluruh manusia yang hidup di dunia ini bisa berhubungan satu sama lain.

Terkait trasnformasi kurikulum tersebut, terdapat beberapa pendekatan yang perlu diperhatikan oleh pesantren berbasis multikultural sebagai berikut:

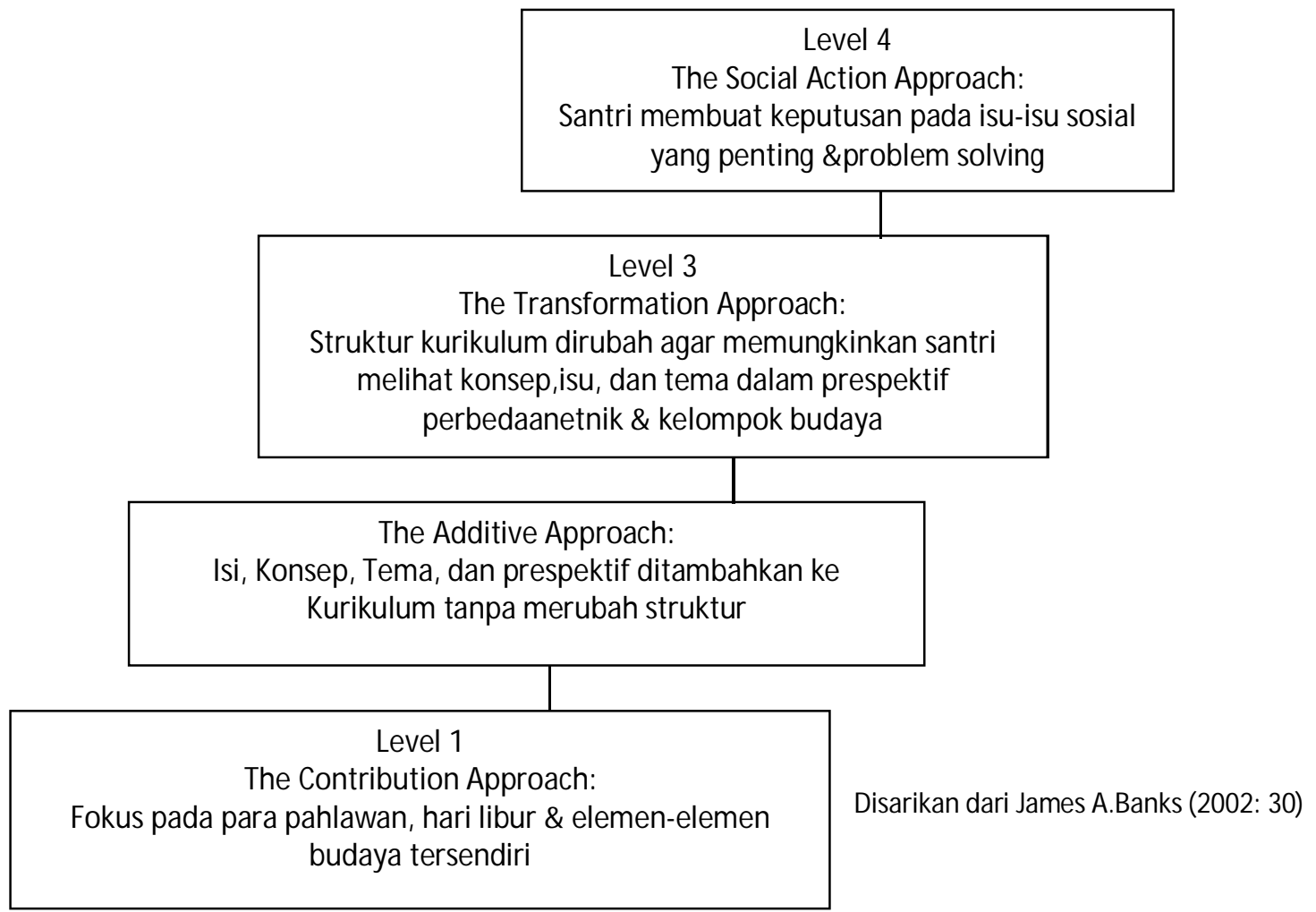

Gambar 1. 
Selain perlu mereformasi kurikulum, dalam rangka menuju Transformative Learning, pesantren sebaiknya juga merubah pendekatan yang selama ini dipakai dan biasanya terpusat pada kiyai dan cenderung monolog (satu arah). Maka pendekatan yang relevan adalah lebih menitikberatkan pada pendekatan yang lebih mengalir dan komunikatif. Agama para santri yang memiliki berbagai aliran dan mazhab pun, dapat dijadikan sebagai materi untuk didiskusikan dan didialogkan dengan mencoba membandingkan dengan aliran, agama dan kepercayaan orang lain. Sehingga, pada tataran ini, mereka dapat menemukan momentum untuk saling mengenal dan menghormati keanekaragaman budaya dan agama.

Model dialog dan perbandingan tersebut jangan berhenti pada tataran wacana saja, seperti yang selama ini berlaku di dalam pendidikan kita atau di pesantren. Bahkan hanya terkesan membanding-bandingkan saja antara satu agama dengan agama lainya. Tetapi harus bisa lebih dari itu, dengan membuat wahana yang memungkinkan para peserta didik bergaul dan berinteraksi secara langsung dengan orang yang memiliki perbedaan keimanan. Harapanya, meminjam ungkapan John S.Dunne (1972), para peserta didik bisa melakukan "melintas" (passing over), melintas dari satu budaya kepada budaya lain. Kemudian diikuti oleh proses yang sama dan berlawanan yang disebut dengan "kembali" (coming back), kembali dengan wawasan baru kepada budaya sendiri, cara hidup dan agama sendiri.

Untuk merealisasikan gagasan pendidikan yang mengedepankan sikap saling menyayangi kepada seluruh manusia tersebut, tentu saja harus didukung dengan kiyai-kiyai yang berwawasan multikulturalisme. Sebab, semua maklum sesungguhnya kiyai/guru dalam pendidikan memegang kunci (key Person). Mustahil jika berkeinginan memproduk manusia yang mampu melintas batas tradisi dan keagamaan orang lain, sementara kiyainya sendiri berwawasan sempit. Kiyai pesantren seharusnya selain harus memiliki ilmu pengetahuan agama yang luas sekaligus berwawasan kebangsaan serta beraqidah inklusif untuk mengajar materi agama kepada anak-anak kita. Semua ini, demi terciptanya harmonisasi dan kehidupan beragama yang ramah, saling menyapa dan berinteraksi satu sama lain di Republik tercinta.

Terkait pesantren harus memililiki seperangkat isi atau bahan yang akan ditransformasikan kepada peserta didik agar menjadi milik dan kepribadiannya sesuai dengan identitas di masa depan. Pesantren perlu melakukan transformasi kurikulum , sebagaimana penjelasan James A. Bank (2002: 21) yang memungkinkan perubahan paradigma kiyai-santri dalam melihat perbedaan ras, etnik, kultur dan kelompok gender.

Untuk keperluan itu, sudah saatnya dalam menyusun kurikulum pesantren dapat memperhatikan asas-asas pembentukan kurikulum seperti; asas agama, filosofis, psikologis dan sosiologis. Pesantren harus menyusun kurikum yang baik, yaitu kurikulum yang menyediakan bahan-bahan yang dapat membantu murid, pemuda dan orang dewasa untuk berkembang. Jadi kurikulum yang baik adalah seperti fungsi suatu laboratorium. Ia selalu rentetan kontinyu suatu eksperimen dalam semua pelakunya (kiyai dan santri). Kurikulum pesantren bersifat lentur, eksploratif, dan 
mencoba apa yang belum bisa dicoba, bergerak secara dinamis, serta mampu mendorong perkembangan minat, berperilaku dan kemampuan praktis. Sedangkan kalau meminjam ungkapan John D. Mc Neil (1998: 5), pesantren perlu membagi kurikulum ke dalam empat bagian yaitu; pertama, kurikulum yang berorientasi pada Humanistik. Kurikulum dengan demikian harus berorientasi bagi pertumbuhan dan integritas pribadi santri secara bebas dan bertanggung jawab. Kedua, kurikulum bercorak rekontruksi sosial. Maksudnya, kurikulum sebagai alat untuk mempengaruhi perubahan sosial dalam menciptakan masa depan yang lebih baik bagi masyarakat. Ketiga, bercorak tekhnologis, melihat kurikulum sebagai proses teknologi untuk mewujudkan tujuan yang dikehendaki pleh pembuat kebijakan. Keempat, kurikulum yang berorientasi akademik, hal ini sebagai upaya peningkatan intelektual dengan cara memperkenalkan santri terhadap berbagai macam pelajaran yang terorganisir dengan baik.

Proses pendidikan pesantren harus senantiasa mencoba membantu para santri untuk membangun identitas mereka secara kultural, nasional dan global sekaligus. (Banks, 2007: 2425).

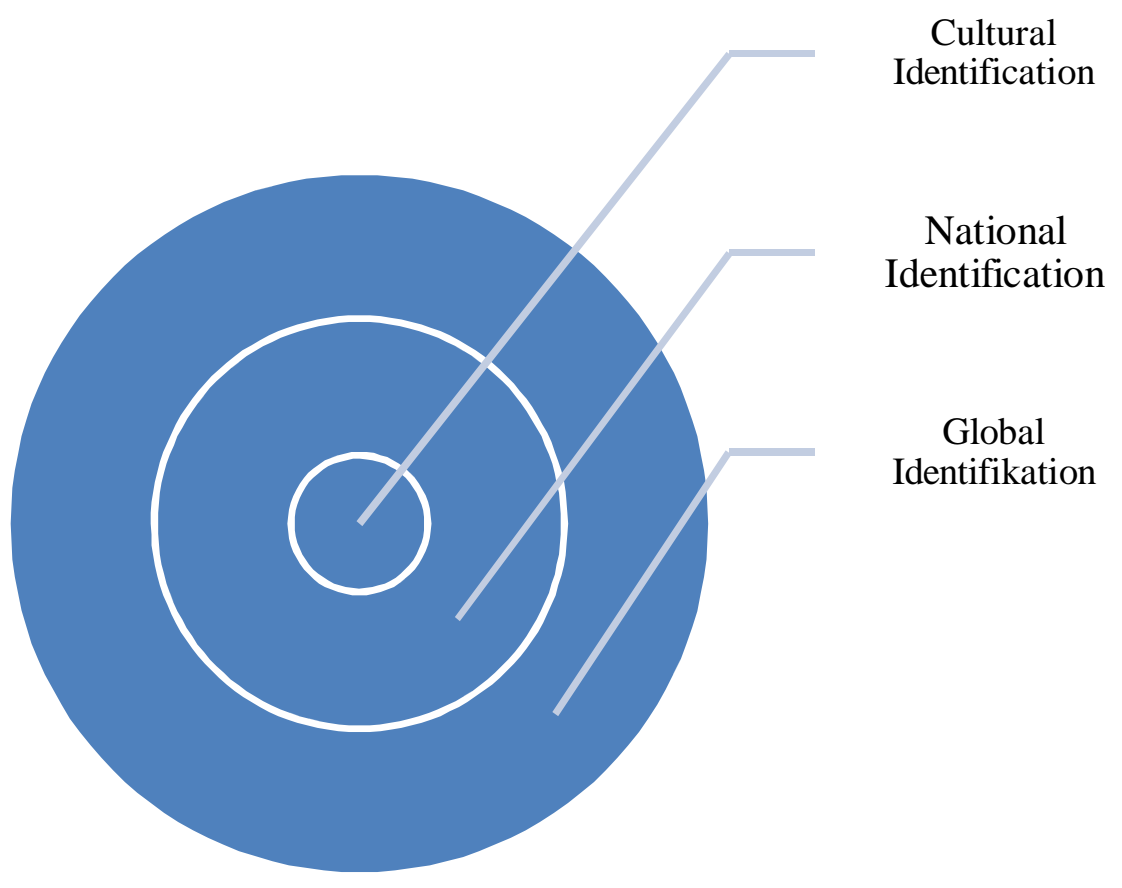

Gambar 2.

Dimana untuk keperluan seperti itu, pesantren perlu membuat kurikulum yang bisa membentuk karakter khusus para santri untuk bisa berperilaku sesuai dengan norma dan nilainilai pesantren. Mereka masih menghormati kiyai, ta'dzim pada ustad, serta mencium tangan ketika bertemu dengan para sesepuh.
Dan demi kepentingan nasional mereka tidak sungkan atau canggung untuk berinteraksi dengan masyarakat dengan latarbelakang agama dan etnis yang berbeda—apalagi sampai memiliki logika berfikir yang antagonistik, yaitu sering menilai kelompok yang satu lebih baik dari kelompok yang lain. Jawa lebih mulia dari luar jawa, kulit putih lebih baik dari kulit hitam, 
dan seterusnya. Sikap meremehkan budaya orang lain dan menganggap budaya sendiri lebih unggul seperti ini oleh Donna M. Gollnick \& Philip C. Chinn (2006: 19) disebut dengan istilah Ethnocentrism. Biasanya ditandai dengan ketidakmampuan untuk melihat budaya orang lain sejajar dan sebagai alternatif yang dapat hidup terus untuk mengatur realitas.

Bahkan kalau bisa, para santri jebolan pesantren mampu ikut menetralisir stereotip dan prasangka antarkelompok yang biasanya menurut Gordon W. Allport disebabkan oleh faktor keterlibatan struktur masyarakat dimana seseorang bertempat tinggal, tradisi budaya dan ekonomi yang berlangsung lama (Noel, 2000: 94). Prejudice yang sudah terbentuk dan beredar dalam masyarakat seperti ini, para santri harus berusaha menghilangkanya, demi persatuan dan kesatuan bangsa Indonesia. Lebih-lebih setelah melihat realitas adanya banyak konflik, kekerasan, dan bahkan kekejaman yang dijalankan atas nama agama, yang terjadi belakangan. Jelasnya, pesantren harus merefleksikan tujuan pendidikan pesantren yaitu; mampu melakukan transformasi kehidupan beragama itu sendiri dengan melihat sisi ilahi dan sosial-budayanya. Pesantren harus mampu menanamkan cara hidup yang lebih baik dan santun kepada peserta didik. Sehingga sikap-sikap seperti saling menghormati, tulus, dan toleran terhadap keanekaragaman agama dan budaya dapat tercapai di tengah-tengah masyarakat plural.

Lebih dari itu pesantren juga harus berwawasan global. pendidikan juga harus mampu mengembangkan logika pluralitas, yaitu logika yang mengakui bahwa semua hal itu berbeda, tak ada yang sama, dan semua yang berbeda-beda itu mempunyai hak untuk hidup dan berkembang. Para santri harus diajak menyadari bahwa sebagian besar keunikan kita itu ditentukan oleh kondisi alam dan budaya, dan sebagian lagi ditentukan oleh pilihan masing-masing individu. Akhirnya, merekapun akan menyadari bahwa tidak semua keunikan di dunia ini dibentuk oleh pilihan bebasnya sendiri. Mereka tidak bisa dengan bebas memilih menjadi perempuan atau laki-laki, menjadi anak gedongan atau hidup dibawah jembatan, atau ingin memiliki tubuh semampai atau gendut, hidung mancung atau pesek, berambut kriting atau lurus, dan seterusnya.

\section{PERAN PENTING PESANTREN DALAM MASYARAKAT MULTIKULTURAL}

Menghadapi realitas kemajemukan di Indonesia serta munculnya fenomena kekerasan atas nama agama dan sekaligus membendung sikap prejudice, saling bermusuhan antara orang-orang yang beragama, maka diperlukan langkah prefentif dan memiliki orientasi jangka panjang, yaitu melalui jalur pendidikan. Pesantren sebagai salah satu lembaga pendidikan agama juga dituntut berperan aktif mensosialisasikan dan membangun perdamaian untuk saling menghormati dan mencintai sesama manusia.

Pesantren perlu menanamkan kesadaran akan karakteristik multikultural sebagai realitas bermasyarakat dan perlunya memegang teguh sifat tenggang rasa dan toleransi yang menurut Zamroni akan melahirkan suatu kesadaran baru bahwa kerjasama dengan segala perbedaan merupakan kebutuhan mutlak yang tidak bisa ditinggalkan (zamroni, 2011: 115). Kesadaran seperti ini tentu tidak akan bisa muncul dengan 
sendirinya dengan baik, melainkan diperlukan rekayasa, yakni suatu upaya yang disadari dan direncanakan-termasuk lewat pendidikan pesantren ini.

Penyemaian bibit-bibit untuk bisa saling mengormati dan mencintai sesama manusia yang memiliki keanekaragaman budaya, agama dan etnis lewat materi yang disediakan pesantren adalah mutlak diperlukan. Semua itu, agar para santri sebagai generasi muda di kemudian hari, terbiasa dan trampil berkomunikasi dengan masyarakat lain. Sekaligus, para santri memiliki "etika global" untuk ikut melestarikan paham multikulturalisme ini di tengah-tengah masyarakat. Agar mereka dengan seluruh elemen masyarakat bisa bergandengan tangan, saling tergantung dan menanggung nasib secara bersama-sama demi terciptanya perdamaian abadi.

Kenapa pesantren dianggap sebagai instrumen penting? Sebab, pesantren adalah sebuah lembaga pendidikan dan "pendidikan" sampai sekarang masih diyakini mempunyai peran besar dalam membentuk karakter individu-individu yang dididiknya, dan mampu menjadi "guiding light" bagi generasi muda penerus bangsa (John Sealy, 1986). Dalam konteks inilah, pesantren sebagai media penyadaran umat perlu membangun inklusifitas demi harmonisasi agama-agama (yang telah menjadi kebutuhan masyarakat agama sekarang).

Lebih dari itu, sebagai sebuah lembaga pendidikan, pesantren merupakan aspek kehidupan yang sangat penting, satu hal yang tak bisa dipisahkan dari masyarakat, terutama sekali pada masing-masing manusia. Semuanya harus saling merefleksi dan terlibat dalam arus perubahan. Keterlibatanya tidak hanya sebatas pada kemampuan untuk mengadakan peyesuaian diri terhadap perubahan, tetapi harus lebih pada bagaimana pesantren itu mampu menjadi agen perubahan sosial.

Hal tersebut sangat mungkin dilakukan, sebab peranan pesantren sebagai sebuah lembaga pendidikan yang oleh Roberta $M$. Berns (2004: 157) disebut sebagai mikrosystem, sangat mempunyai andil yang besar dalam membentuk watak peserta didik seperti yang diharapkan. Pesantren disini tentu mempunyai fungsi sebagai lembaga sosialisasi dengan cara menyediakan pengalaman (belajar) intelektual dan sosial yang dengannya anak mengembangkan kecakapan (skills), minat, dan sikap yang akan mensifati dirinya (menjadi karakteristiknya) sebagai individu dan yang akan membentuk kemampuannya menjalankan peran sebagai orang dewasa kelak.

Jadi pesantren ke depan yang berbasis multikultural harus berupaya untuk mempersiapkan para santri dalam menghadapi kehidupan. Maksudnya, di samping pesantren harus mempersiapkan para santri agar mampu mandiri, berinteraksi dan berkompitisi di era globalisasi sekaligus mempunyai keimanan kuat, memegang tradisi keislamanan, juga dituntut mampu menunjukkan perilaku yang baik, seperti menjaga keharmonisan dengan agama-agama lain—sebagai buah dari keimanan dan keislamanya.

Itulah tantangan pesantren masa depan, yang tidak hanya bertanggung jawab melestrasikan nilai-nilai moralitas khas pesantren sebagaimana sering diajarkan dalam kitab-kitab kuning, tetapi juga ikut melestarikan 
dan membudayakan paham kemajemukan. Pesantren harus mengajarkan kepada para santri bahwa perbedaan adalah fakta dan realitas yang dihadapi manusia sekarang. Maka, mereka didorong menuju kesadaran bahwa multikukulturalisme memang sungguh-sungguh fitrah kehidupan manusia. Dengan meminjam unkapan Ki Hadjar Dewantara (2004: 227-228), pesantren perlu menerapkan "Asas Tri-Kon”, yaitu kontiyuitas: pesantren sekarang harus melanjutkan kehidupan masa silam. Konvergensi: pesantren perlu bertemu dengan masyarakat lain dan tidak terisolasi, dan ketiga, konsentrisitas: setelah bertemu dengan nilainilai dan kebudayaan masyarakat lain, pesantren jangan kehilangan identitas.

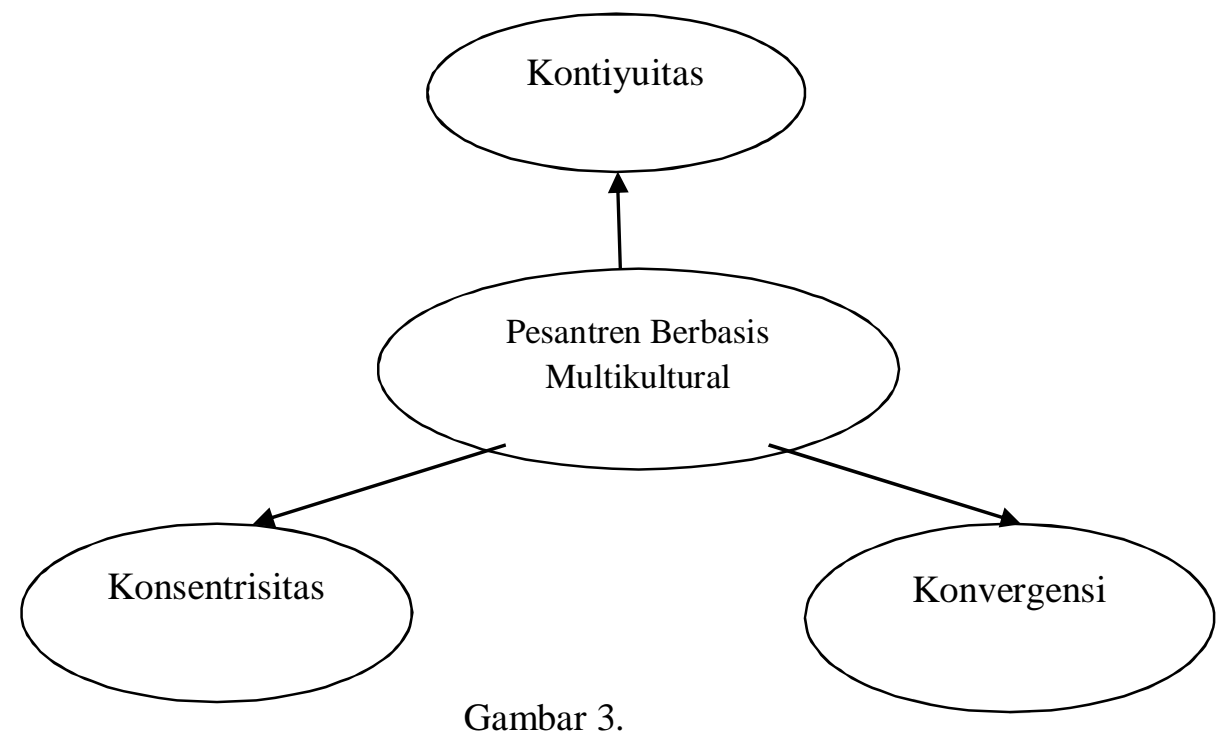

Pesantren harus sadar, bahwa hidup di negeri yang terkenal majemuk seperti Indonesia ini perlu bersikap inklusif, humanis dan fleksibel. Pesantren dituntut senantiasa mewariskan ajaran-ajaran luhur yang melekat dalam tradisi pesantren yang terkenal dengan sifat akomodatif dan menghargai kebudayaan agama lain. Karena pada kenyataanya sampai sekarang banyak ditemukan hasil peninggalan di pesantren tradisional-baik berupa budaya maupun seni, yang menggambarkan proses yang disebut Donna M. Gollnick \& Philip C. Chinn (2006: 30) dengan istilah asimilasi. Dimana kelompok budaya yang berbeda dapat menjadi bagian atau menyatu menjadi kelompok dengan mengadopsi budaya dominan. Dalam hal ini antara kebudayaan Islam dan tradisi agama- agama lokal pada masa lampau. Sebagai contoh, tradisi tahlilan, selametan, berjanji, dan lain-lain.

Kebudayaan dan kearifan lokal pesantren seperti itu, dalam prespektif filosofis sebagaimana dinyatakan oleh Aristoteles merupakan salah satu akar adanya kebajikan (Virtue ethics). Local wisdom sangat berperan dalam mengatur penerapan kebajikan yang mana telah menjadi watak umum untuk dilakukan dalam situasi etika khusus. "For virtue makes aim at the right mark, and practical wisdom make us take the right means" (Sprod, 2001:88). Apalagi kearifan local pesantren, sadar atau tidak harus diakui sebagai salah satu faktor yang memiliki kontribusi bagi perekat dan pemersatu masyarakat di tanah air. Tradisi pesantren yang mengandung unsur-unsur lokal tersebut, mampu membangkitkan semangat kebersamaan dan 
persaudaraan diantara masyarakat dengan perbedaan keimanan dan keyakinan.

Dengan begitu, pada tataran teologis, pesantren pada wataknya adalah bukan pasif, tektualis, dan eklusif. Melainkan menerapkan teologi yang saling menghormati, saling mengakui eksistensi, berfikir dan bersikap positif, serta saling memperkaya iman. Hal ini dengan tujuan untuk membangun interaksi umat beragama dan antarumat beragama yang tidak hanya berkoeksistensi secara harmonis dan damai, tetapi juga bersedia aktif dan pro-aktif kemanusiaan.

\section{MENGEMBANGKAN KULTUR INKLUSIFISME PESANTREN}

Mengembalikan citra pesantren sebagai lembaga yang senantiasa mengajarkan toleransi umat beragama dan humanis sangat memungkinkan. Terutama sekali pesantren pada dasarnya telah memiliki watak inklusif dan terbuka dengan perbedaan. Maka salah satu upaya untuk membentengi para santri agar terhindar dari radikalisasi agama, pesantren harus senantiasa melestarikan dan mengembangkan nilai inklusifisme pesantren.

Pesantren harus membentuk kultur demokratis, ini penting sekali untuk menunjang transformative learning di pesantren berbasis multikultural. Dimana kultur sebagaimana penjelasan Zamroni (2011: 45) merupakan totalitas, organisasi way of life, termasuk nilainilai, norma, lembaga dan karya yang diwariskan antar generasi, dipegang bersama yang mempengaruhi pola pikir, sikap dan pola tindakan seluruh warga (masyarakat pesantren).

Apalagi pesantren pada realitasnya telah memiliki kultur positif. Nilai-nilai inklusif untuk menghormati dan menghargai orang lain, telah menjadi semacam kultur di pesantren. Praktik pengajaran yang diterapkan di pesantren juga sudah berbasis multikultur. Sebab, meskipun para santri yang datang ke pesantren biasanya memiliki latarbelakang yang berbeda, dari status ekenomi, budaya dan etnis. Tapi ketika mereka sudah masuk dalam komunitas pesantren biasanya, ada nilai-nilai moralitas yang mengikat mereka untuk berperilaku sesuai atauran-aturan di pesantren. Pesantren dengan begitu, sebenarnya dari awal para santri masuk dan mengenal dunia pesantren-telah mampu memperkenalkan pentingnya persaudaraan diantara para santri yang mempunyai perbedaan latarbelakang-dalam satu ikatan nilai dan moralitas.

Prinsip menghormati dan menolong sesama santri sangat ditekankan di pesantren. Lebih jauh dari itu, dalam literatur-literartur klasik pesantren terdapat anjuran supaya para santri memegang tiga prinsip persaudaraan, yaitu; Ukhuwwah Islamiyyah (Persaudaraan karena agama Islam), Ukhuwwah Wathaniyyah (persaudaraan karena tanah air), dan Ukhuwwah Basyaraiyyah (persaudaraan karena kemanusiaan). Relevan dengan persolan yang terakhir inilah, sebenarnya di pesantren sudah ditanamkan sikap toleransi dan menghargai orang lain meskipun memiliki agama yang berbeda. Bahkan di pesantren sangat terkenal dengan ungkapan lakum dinukum waliyaddin (untukmu agamamu dan untukku agamaku), sebuah prinsip yang bersumber langsung dari alQur'an.

Berdasarkan kenyataan tersebut, tak salah jika seorang peneliti Amerika bernama Ronald A. Lukens-Bull dalam tulisan hasil penelitian 
disertasinya yang berjudul "Teaching Morality:

Javanese Islamic Education In A Globalizing

Era", telah menggambarkan kepada kita betapa para pemimpin pesantren sesungguhnya sangat menanamkan "moralitas tradisional" untuk para santri yang akan berpartisipasi dalam, dan bahkan menyebabkan, Indonesia dalam modernisasi dan globalisasi. Moralitas ini diajarkan dalam pelajaran yang disebut ngaji, yang melibatkan pengajaran dari sebuah teks Arab. Namun, ngaji adalah satu-satunya awal dari pendidikan moral. Para kiyai pesantren biasanya hanya bisa menekankan dan mengajarkan santri tentang agama dan moralitas, tapi mereka tidak bisa mengajarkan para santri untuk menjadi bermoral. Pendidikan moral, dalam arti pengajaran perilaku moral, harus memiliki pengalaman. Pesantren berusaha untuk menciptakan lingkungan di mana moral agama dapat dipraktekkan serta dipelajari (Bull,2000: 40).

Nilai-nilai lain, yang sering diajarkan di pesantren adalah seperti ikhlas (tidak mementingkan diri sendiri) dan kesederhanaan (hidup sederhana). Di pesantren kebanyakan, santri tidur di lantai di ruangan yang dapat menampung hingga delapan puluh siswa lain. Makanan yang sedikit: beras dan sayuran. Selanjutnya, sementara ada pengakuan dari milik pribadi, dalam praktek, properti adalah bersifat komunal. Hal-hal sederhana seperti sandal yang bisa dipinjam secara bebas. Dengan kata lain, jika tidak digunakan, harus dipinjamkan. Para santri yang biasa menolak meminjamkan hartanya akan diberi sangsi oleh rekan-rekannya dan kadang-kadang oleh staf pesantren. Bahkan sebagaimana pengakuan Bull, dia sering kehilangan tape recorder dan kamera. Tetapi, biasanya dikembalikan kemudian, kamera dengan semua film yang digunakan. Bagi santri yang tidak berbagi, sanksi cukup menggoda atau pengingat tegas agar mementingkan artinya persaudaraan Islam dan pentingnya Ikhlas (BulI, 2000: 39-40).

Karakteristik pesantren dalam mengajarkan akhlak pada para santri tidak berhenti pada teori saja tetapi sampai terjadi internalisasi yang mendalam (mendarah daging). Meminjam teori Petalozzi, pengajaran moral di pesantren bukan hanya sekedar mengajarkan kebaikan dengan kata-kata, tapi melalui praktik " language of morality could not be taught by worth of truth, it had to be taught by example practice not preaching was the basis of moral education” (Heafford, 1967:62) (Bahasa moralitas tidak bisa diajarkan lewat nilai kebenaran, tetapi dapat diajarkan melalui contoh praktik bukan mengajarkan dasar pendidikan moral). Maka berbicara tentang inklusifisme pesantren sebenarnya, para kiai telah banyak memberi contoh praktis kepada para santri bagaimana seharusnya berinteraksi dan bergaul di tengah masyarakat yang majemuk. Bukankan para kiai pesantren terkenal pejuang tangguh pancasila? Sebab tercatat dalam sejarah, sebagaimana dinyatakan oleh Mun'im Sirri (2010), pada tahun 1984, adalah tahun bersejarah karena para kiai yang berjuang melalui organisasi NU mengakui idiologi pancasila sebagai asas tunggal.

Oleh sebab itu, ketika terjadi perdebatan di tengah masyarakat terkait isu pesantren sebagai sarang teroris. Justru Mun'im Sirry, melaui tulisannya berjudul "The Public Expression of Tradisional Islam: the Pesantren and Civil Societyin Post-Suharto Indonesia- 
telah menunjukkan kontribusi pesantren dalam membentuk civil society dan demokratisasi masyarakat Indonesia, melalui peranananya dalam menyuarakan tema-tema kebebasan, kesetaraan dan persamaan. Meskipun dengan tipe dan karakter khasnya sebagai lembaga tradisional, bukan berarti pesantren bertentangan dengan nilai-nilai kemodernan. Modern bukan berarti hanya nilai barat saja, melainkan sangat compatible dengan idealitas Islam pesantren (Sirri, 2010: 60-66).

Sebenarnya pesantren dengan keanekaragaman idiologi yang melekat padanya apakah itu masuk katagori pesantren tradisional, modern dan ne-modern. Semua mempunyai misi untuk memperjuangkan Islam sebagai rahamatan lil'alamin. Terutama sekali pesantren telah diakui oleh banyak pakar memiliki banyak kontribusi bagi pembangunan. Pesantren di
Indonesia menjadikan dirinya sebagai bagian dari proyek modernisasi. Sebenarnya perbedaan tradisonal dan modernis, di samping dibalik makna terminologinya, juga pada visinya masing-masing dalam vis-a-vis Negara. Karena menurut Sirri (2010: 66) sepanjang konflik dengan pemerintah aktifis pesantren membayangkan jenis masyarakat sipil yang otonom dari Negara. Bagi mereka, masyarakat sipil harus berfungsi sebagai pengawas atau pembatasan kritis pada pemerintah. Sementara itu, pemikir Muslim modernis dan neo-modernis melihat masyarakat sipil lebih terfokus pada pengembangan nilai-nilai toleransi, pluralisme, dan kesopanan, tetapi tidak selalu melihat masyarakat sipil sebagai terpisah dari, dan tentu saja tidak selalu oposisi pada Negara. Jika dibuat gambar adalah sebagai berikut:

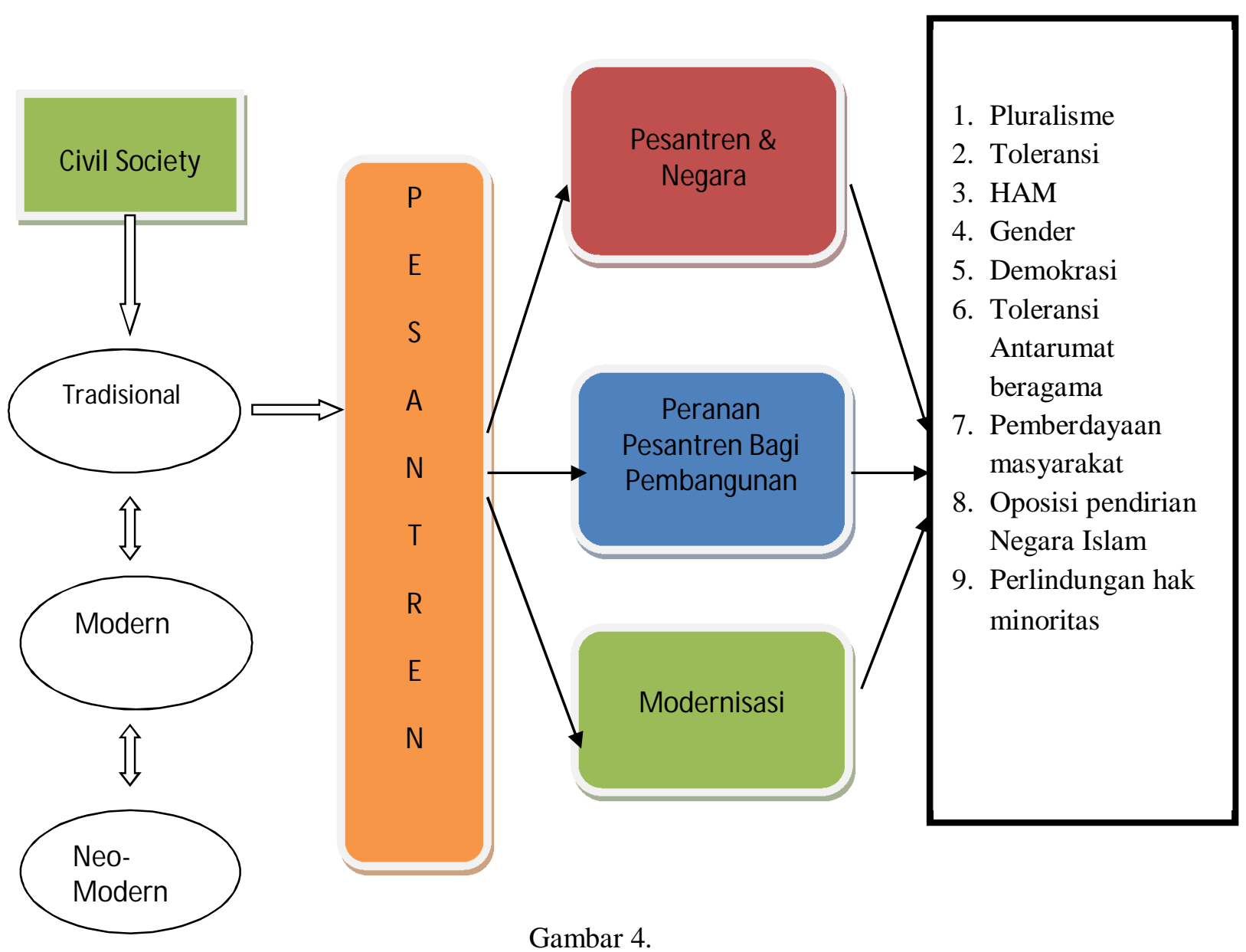


Pesantren dengan perbedaan jenisnya apakah masuk pada katagori modern yang diwakili oleh Muhammadiyah dengan tokohnya Amin Rais, Buya Syafii Ma'arif, Din Syamsuddin, tradisional oleh NU dengan tokohnya KH. Abdurrahman Wahid, KH Muhammad Hussein, neo-modernis dengan tokohnya Nurcholis Madjid memang mengembangkan kultur yang berlainan dan asik kalau dicermati. Sebab mereka memiliki perbedaan pada artikulasi politik atau vis-avisNegara, tapi bisa bertemu pada satu aspek yaitu; sama-sama memperjuangkan nilai-nilai moralitas dan kemanusiaan seperti: hak-hak agama minoritas menegakkan dan prinsip toleransi terhadap semua orang lain supaya bisa hidup berdampingan dalam damai dan harmoni. Kultur bisa menerima perbedaan di pesantren seperti inilah yang harus senantiasa ditransmisikan dari satu generasi kegenerasi selanjutnya demi keutuhan Negara republik ini.

\section{KESIMPULAN}

Pesantren sebagai bagian dari sistem pendidikan di Indonesia adalah salah satu bentuk perwujudan kebudayaan manusia yang dinamis dan sarat perkembangan, karena itu perubahan atau perkembangan pesantren adalah hal yang memang seharusnya terjadi sejalan dengan perubahan budaya kehidupan. Perbaikan pesantren perlu terus dilakukan sebagai antisipasi kepentingan masa depan. Pemikiran ini mengandung konsekuensi bahwa transformative learning dalam upaya menumbuhkembangkan pesantren berbasis multiKultural perlu langkah-langkah penyempurnaan atau perbaikan dari aspek kurikulum, tujuan dan metode pesantren. Semua itu dalam rangka untuk mengantisipasi kebutuhan dan tantangan masa depan dengan diselaraskan terhadap perkembangan kebutuhan masyarakat global. Sebuah masyarakat yang mengharuskan semua manusia yang hidup di dalamnya saling menghormati dan mencintai tanpa membedakan latarbelakang agama, kebudayaan dan etnis. Konsep pesantren yang "dipercaya" mampu menjawab kebutuhan global seperti ini adalah pesantren yang berbasis multikulturalisme dan pluralisme. Melalui pesantren seperti inilah kerinduan akan rasa damai dan menyayangi antar sesama manusia di dunia ini akan terwujud.

Pesantren berbasis multikultural dengan transformative learning harus merancang kurikulum yang ideal yaitu kurikulum yang dapat menunjang proses siswa menjadi manusia yang demokratis, pluralis dan menekankan penghayatan hidup serta refleksi untuk menjadi manusia yang utuh, yaitu generasi muda yang tidak hanya pandai tetapi juga bermoral dan etis, dapat hidup dalam suasana demokratis satu dengan lain, dan menghormati hak orang lain. Kurikulum pesantren berbasis multikutural mestilah senantiasa mengembangkan dari kajian-kajian kitab kuning, yang menjadi referensi pokok untuk bisa beradaptasi dengan perkembangan globalisasi. Pesantren juga mengembangkan materi atau subjek seperti: toleransi, tema-tema tentang perbedaan ethnokultural dan agama: bahaya diskriminasi: penyelesaian konflik dan mediasi: HAM; demokrasi dan pluralitas; kemanusiaan universal dan subjek-subjek lain yang relevan. 


\section{DAFTAR PUSTAKA}

Banks, James A. (2007), Education Citizens in a Multicultural Society, New York \& London: Teacher College Press.

Bank, James A. (2002), An Introduction to Multicultural Education, Boston: Allyn \& Bacon.

Dhofier, Zamakhsari (1994), Tradisi Pesantren Studi Tentang Pandangan Hidup Kyai, Yogyakarta: LP3ES.

Gollnick, Donna M. (2006), Multicultural Education in a Pluralistic Society, Ohio: Pearson MerrilPrentice Hall

Ladson-Billings, Gloria \& Gillborn, David (2004), Ruotledge Falmer Reader in Multicultural Education, London \& New York: RoutledgeFalmer.

Lukens-Bull, Ronald A. (2000), "Teaching Morality: Javanese Islamic Education In A Globalizing Era", Journal of Arabic and Islamic Studies 3.

Lukens-Bull, Ronald A. (2000), Teaching Morality: Javanese Islamic Education in a Globalizing Era, Journal of Arabic and Islamic Studies 3, JACKSONVILLE: UNIVERSITY OF NORTH FLORIDA.

Noel, Jana (2000), Multicultural Education, USA: McGraw-Hill Companies.
Heafford,Michael (1967), Pestalozzi His thought and its relevance today, London: Methun \& CO LTD.

Rodger, Alex R. (1982), Educational and Faith in Open Society, Britain: The Handel Press.

Sealy, John (1986), Religious Education: Philosophical Perspective, London: George Allen dan Unwin.

Sprod, Tim (2001), Philosophical Discussion in Moral Education: The Community of Ethical Inquiry, USA \& Canada: Routledge.

Sirri, Mun'im (2010), The Public Expression of Traditional Islam:the Pesantren and Civil Society in Post-Suharto Indonesia, The Muslim Word,Vol. 100, Januari.

Zamroni (2011), Preparing Multicultural teacher educators: toward a pedagogy of transformation dalam "Research on multicultural education a reader, Yogyakarta: Graduate Program the State Universityof Yogyakarta.

Zamroni (2011), Pendidikan Demokrasi pada Masyarakat Multikultural, Yogyakarta: Gavin Kalam Utama 